\title{
INTERCULTURAL LEARNING: CHALLENGES FOR CURRENT SCIENCE EDUCATION
}

\author{
Martin Bílek \\ Charles University, Czech Republic
}

In the time of curricular reforms across the Europe another chance appeared towards increasing learners' interest in science education, particularly in relation to the future job selection in the field of natural sciences and technology. Innovations in natural science instruction can be conducted in various ways, e.g. (Bílek \& Klečková, 2006): (1) learners' interest in natural sciences and their instruction (What am I interested in?; What would I like to learn?; What learning content should be learned?) - answers to these questions were discussed i.e. in the analysis of the international comparative study ROSE (Relevance of Science Education) (ROSE Project, 2018), (2) context of instruction (optimally -"school science", application context, social context, personality context), (3) learning content (standards; Framework and School programmes; traditions; new topics) or (4) competences (key competences; "scientific literacy"; activities in natural science). The current approach to instruction in schools is characterized mainly by the dominant position of the teacher and receptive passivity of learners. Scientific knowledge is built in such a form, which nearly excludes its application and exploitation in the future. Learners are not able to use the knowledge in real situations because they do not discover its relation to the reality; they are not able to apply the abstract knowledge in the real situation. The teacher should create content-rich communicative environment which will address the subjective knowledge area and at the same time which contains new puzzles inviting to creative self-orientation. The teacher's art lies in the ability to forecast the chain of consequences between original construction of the reality with the learner and scientific knowledge which the learner understands as the state of expected conflict, solves it via the trial-error way. The attention is paid to the individual with subjective content of knowledge and experience (Bílek, Rychtera \& Chroustová, 2017).

New challenge penetrating through all above mentioned "ways" and "problems" of science education is intercultural aspect, intercultural teaching and learning in science education. Making interculturality come alive in European society is the core to our future development: In the last ten years the number of asylum seekers, e.g. in Germany, has risen from around 30.000 a year in 2005 to about 440.000 in 2015 . Forecasts indicate that $50 \%$ of future pupil generations will have migrant background. If we want a stable, socially cohesive society, activities which allow for intercultural learning, exchange and dialogue are urgently needed (IncluSMe Project, 2016).

How to connect maths and science educational content and intercultural aspects? How to include different social, cultural, religion, historical, ethical contexts into maths and science classroom? It is really a challenge also for maths and science education or it is a case of social sciences only?

Answers to formulated questions are not so simple, but experiences from the intercultural classrooms (schools) present that maths and science education have to include these aspects, too. Maths and science principles, phenomena or laws are the same in all the world, it means they are global, but their instruction, their explanation has a higher efficiency if they are connected with social, cultural, religion, historical, ethical and other approaches which are mainly really local.

In the educational reality we can find recently different contributions to implementation of intercultural context into curriculum, but maths and science education is not frequently included. The ambience to fill this gap has the current project from framework Erasmus+ with acronym IncluSMe. The acronym means "Intercultural Learning in 
Mathematics and Science Initial Teacher Education" and project activities focus on increasing the quality of the initial teacher's education of prospective mathematics and science teachers by including intercultural learning into their curricula: Prospective mathematics and science teachers need to learn how to cope with language barriers, culturally different pre-concepts about science and highly varying proficiencies of students (immigrants including) to be prepared to tackle the challenges of their future profession (IncluSMe Project, 2016).

In turn, maths and science competences are crucial for civic participation, academic and professional success, not only for students with diverse backgrounds but for all. But if comprehension and communication problems due to language barriers or cultural differences are not addressed, mainly students with immigrant background may perform poorly in maths and science. In order to secure educational opportunities for immigrant and refugee youth, it is essential to include intercultural aspects into the initial education of maths and science teachers. Aims of the project IncluSMe are to improve the relevance of higher education curricula for prospective maths and science teachers by linking maths and science education with intercultural learning - and thereby strengthening students' social, civic and intercultural competences. The project brings together 11 teams of higher education institutions for initial teacher education from across Europe comprising experts in maths and science education, in inclusion and diversity, in mobility and intercultural learning, as well as people involved in pilot projects for refugees: University of Education Freiburg, Germany (coordinating institution), University of Nicosia, Cyprus, University of Hradec Králové, Czech Republic, University of Jaen, Spain, National and Kapodistrian University of Athens, Greece, Vilnius University, Lithuania, University of Malta, Malta, Utrecht University, Netherlands, Norwegian University of Science and Technology, Norway, Jönköping University, Sweden and Constantine the Philosopher University, Slovakia. Each one from the cooperating institutions is preparing their own module with a topic close to integration of maths and science content and intercultural aspects. Disseminations are oriented to offering international summer schools and multiplier events and to strengthen transnational cooperation between universities in establishing mobility programmes for maths and science students in initial teacher education. Web page of the project is accessible at the link https://inclusme-project.eu/.

For intercultural learning, first-hand experiences are indispensable and in particularly relevant for the future classroom. Yet, prospective science teachers need to be aware of the cultural realities of many science tasks as well as of culturally different algorithms. They should be able to perceive culturally different perspectives and develop intercultural sensitivity. From these reasons the first common activity was prepared with selected, science-oriented modules, International Summer School in Prague, a beautiful city in the heart of Europe with great opportunities to meet and recognize multicultural society and intercultural relations. Venue in Prague offered to discover"genius loci" connected with intercultural feeling and rich historical memory. Participating students of the first IncluSMe Summer School had numerous opportunities for intercultural exchange, both within the international student group and outside when meeting local students, teachers and pupils. This enabled them to gain rich intercultural experience connected to their own future profession - science teacher. Students had a profit from the summer school as an excellent opportunity for gaining international and intercultural experiences which enabled them to better appreciate and understand cultural and social diversity. During the summer schools, students lived and worked in an intercultural setting together with students from 7 different European countries, having numerous opportunities for intercultural communication.

The programme provided lectures and workshops on intercultural science learning, as well as offered activities to make own experiences in the working place: for example, visits to Czech schools and non-governmental institutions connected with different intercultural contexts, to recognize climate of middle European city with rich historical and intercultural heritage etc.

During the summer school the following topics were held, it means the following IncluSMe modules were selected for lectures, seminars and lab or field works: (A) Intercultural competencies - Accompanying prospective teachers in making intercultural experiences (team of lecturers from the Jönköping University, Sweden in cooperation with the teams of lecturers from the other participating universities organized in sending to institutions before Summer School), (B) Intercultural science learning outside of school - Diversity in school, diversity in nature (team of lecturers from the Norwegian University of Science and Technology, Norway), (C) Culture-related context for mathematics and Science Education (team of lecturers from the Utrecht University, Netherlands), (D) Different perspectives on current ecological problems - The example of water (team of lecturers from the University of Hradec Kralove, Czech Republic), (E) Relevance of language in science education (team of lecturers from the University of Nicosia , Cyprus), Scientific problems involving moral, ethical or cultural aspects - Use of socio-scientific scenarios to enhance science learning in culturally diverse classrooms (team of lecturers from the University of Jaen, Spain) 
and Assessment in mathematics and science in multicultural contexts (team of lecturers from the University of Malta, Malta).

Participating students were prepared for their stay abroad by being sent to institutions with the help of Module A, raising students' intercultural awareness and preparing them for a stay in a country where they do not understand the local language. During their stay they had numerous opportunities for intercultural communication both within the international student group and outside when meeting the local population and local minorities. This enabled them to gain rich intercultural experience. The programme was realised at Faculty of Education Charles University and offered students the opportunity to perceive and analyse different aspects of science education in its interrelation with cultural, national, religious and other dimensions of society, as well as current ecological problems. In the programme participated 26 university students, future teachers, from 7 countries: Czech Republic (5), Slovakia (5), Spain (5), Norway (3), Sweden (3), Cyprus (3) and Malta (2).

By student's evaluation Summer School was evaluated very positively for the interesting content, positive climate and working atmosphere. Project partners received a very good experience from the Summer School realisation and all recommendations and comments will be used mainly in the second Summer School, which will be oriented to intercultural learning in maths education and will be organised by partners from Vilnius University in Lithuania, in 2019. The focus is now oriented to the next activities like research based on questionnaires and interview realised by leading of NTNU team, individual module evaluation questionnaires, analysing of student's portfolios etc. Transnational collaboration between the lecturing partners was very high with great support from students, participants of the Summer School as well as students from hosting institutions. Receiving results from prepared modules and their realisation during the Summer School are very promising and can propose new ways in science teacher's education. Finalised versions of modules directly allow completing the curriculum for future science teachers and they as well can ensure continuing education of teachers from the practice.

What to add at the conclusion? Maybe one sentence from students participating in IncluSMe Summer School in Prague: "... it is a new point of view. For me, mathematics and science are not connected with culture. It is rather a domain of history and geography. But now I think I was wrong. That's why I think everything was GREAT!"

\section{References}

Bílek, M., Rychtera, J., \& Chroustová, K. (2017). Identification of key and critical points in early chemistry curriculum in Czech Republic. In Lamanauskas, V. (Ed.), Science and technology education: Engaging the new generation, Proceedings of the $2^{\text {nd }}$ International Baltic Symposium on Science and Technology Education - BalticSTE 2017 (pp. 25-27). Šiauliai: Scientia Socialis.

Bílek, M., \& Klečková, M. (2006). K možnostem inovace výuky chemie na základní škole v době kurikulární reformy [On current possibilities of innovation in chemistry instruction at basic school within the curricular reform]. In Kričfaluši, D. (Ed.), Aktuální aspekty pregraduálni prípravy a postgraduálního vzdělávání učitelů chemie (pp. 13-16). Ostrava: PřF OU.

ROSE Project. (2018). Retrieved from https://roseproject.no/.

IncluSMe Project. (2016). Retrieved from https://inclusme-project.eu. 